【論 文】

\title{
少数種類の構造物からなるライフライン システムの耐震性の評価
}

\author{
SEISMIC RISK ANALYSIS OF LIFELINE SYSTEMS \\ COMPOSED OF A FEW KINDS OF STRUCTURES
}

\author{
川上 英 二* \\ By Hideji KAWAKAMI
}

\section{1. 序論}

上下水道・電気・通信・鉄道・道路等のライフライン システムは，近年，産業および国民生活にとって基本的 な機能を果たしており, 地震国日本においては，これら システムの地震時における機能の安全性を保つことが地 震災害を減少するために重要であると考えられている. ライフラインシステムの機能の安全性を向上させるため 従来, 2 つの方法一一各構造物の構造上の強度を増加す るといら方法と, システムの形状を合理的に定めて機能 の安全性を増加するといら方法一一がとられている. そ れに伴い多くの研究が行われ, 特に前者の方法に関する 研究は多く, 現在までの研究により, ライフラインシス テムを構成する各構造物の構造上の強度はかなり明らか になってきている ${ }^{1)}$. しかし, 後者の方法に関する研究 は以下に示すように，まだ緒についたばかりである.

久保 ${ }^{2)}$ は関東地震による水道管の被害分布を統計的に 整理し, 地盤特性と水道管の被害との関係を求めてい る. 一方, Panoussis ${ }^{3)}$ は直列・並列システムの組合せ から構成される簡単な形状のライフラインシステムの地 震に対する信頼性を定量的に評価している. この研究を Taleb-Agha ${ }^{4)}$ はさらに進め, Tie-set, Cut-set の考え を用いて,さらに複雑なライフラインシステムの信頼性 を評価するための方法を展開している. 以上の研究を工 学的に意味あるものにするため, Shinozuka ・ Takada・ Kawakami $^{5)}$ 汢地盤の影響を考慮して地中埋設管シスう ムの信頼性を評価している. 一方, 柴田・土屋 ${ }^{6)}$ はブー ル代数を利用した方法を用いて, 電力網システムの信賴 性を評価している. また, 田村・川上文 99 はモンテカル ロ法を用いてシステムの信頼性を評価し, さらにライフ ラインシステムのおのおのの特性を考慮して, その機能 の信頼性をシミュレーションを用いて評価している. 伯

* 正会員 工博 埼玉大学助手 工学部建設工学科
野・斎藤 ${ }^{(0)}$ はシステムの信頼性に影響を与える因子につ いて重回帰分析を用いた研究を行っている.

しかし, 以上提案されている方法はどれも, システム の形状を一定とし，地震荷重を確定量をたは特定の分布 をする確率量であると仮定した場合のシステムの信頼性 を报って却り，いろいろな大きさの地震荷重が作用した 場合のシステムの信頼性の変化を算定するためには, あ るいは複数のシステムの信頼性を比較するためには, 多 くの地震荷重と複数個のシステムとのそれぞれの組合せ に対し，システムの信頼性を算定し，その值の変化を調 べる必要があり，膨大な計算量が必要となる．以上の結 果を簡単に見通しょく求める方法が望まれていると考え る. また従来, 構造系の信頼性解析として, 静定構造物 および不静定構造物に対して信頼性解析の方法が研究さ れているが, 外力に対し, システム全体で力学的に抵抗 する役割を果たす構造系とは異なり，ライフラインシス テムは各構造物の破壊により生ずるシステムの機能低下 に対して, システムを並列化, または攵長度を増加させ ることにより, システム全体で機能低下に抵抗する役割 を果す，いわば機能系である．また，一般に破壊モード む多種多様である.したがって，このようなライフライ ンシステムに対しても新しい信頼性解析の方法が必要で あると考える。

本論文では, ライフラインシステムの多くは, 少数個 の種類の構造物が多数個集まり, システムを構成し機能 していることに注目して, システムの信頼性を荷重外力 と構造物の強度とから求をる各種類の構造物の信頼性を 用いて算定される関数と, システムの形状をネットワー ク状にすることに影響されるシステムに固有な関数との 2 つの関数で表わす方法を展開した. これら 2 つの関数 の性質を調べ，さらにこれらを用いてシステムの機能の 信頼性を見通しよく求める方法を提案した. 以上の方法 を簡単なシステムのモデルに適用した結果, これらの方 法がシステムの信頼性の算定に有用であることを確認し 
たので報告する．

\section{2. システムの信頼性の評価方法}

\section{（1） 1 種類の構造物からシステムが構成されている 場合}

ライフラインシステムは, 多くの場合, 少数種類の構 造物が多数個集まって1つの機能を果たしている.上下 水道の場合，多数個の管路の集合からシステムがおもに 構成され，鉄道・道路も類似断面をもつ構造物の単位の 集合と考えられる.

1 種類の $m$ 個の構造物から構成されているシステム を考える. ある外力に対して, これらの $m$ 個の構造物 のうち, いくつかのものは破壊し, 残りのものは安全で あったと考える. そして, その結果, システムは安全で あるか破壊であるかいずれかであったと考える。ここ で, 安全であった構造物の個数を $x$ 個とすると, 破壊し た構造物の個数は $(m-x)$ 個であるが，システムが安全 である事象 $S_{s}$ は，構造物が零個安全であり（ $m$ 個破壊 して)，かつシステムが安全である事象，構造物が 1 個 安全であり，かつシステムが安全である事象，‥, 構造 物が $m$ 個安全であり，かつシステムが安全である事象 の $(m+1)$ 個の事象の和集合であり，かつ，これらの事 象は同時には起こり得ず，互いに排反事象である.ここ で $x$ 個の構造物が安全である事象を $A_{x}(x=0,1, \cdots$, m) とおくと, 排反事象に対する確率の加法性より, シ ステムが安全である事象 $S_{s}$ が生じる確率 ${ }_{s} P$ は次のよ うに表わされる.

$$
\begin{aligned}
{ }_{s} P & =\operatorname{prob}\left(S_{s}\right)=\sum_{x=0}^{m} \operatorname{prob}\left(A_{x}, S_{s}\right) \\
& =\sum_{x=0}^{m} \operatorname{prob}\left(A_{x}\right) \cdot \operatorname{prob}\left(S_{s} \mid A_{x}\right) .
\end{aligned}
$$

ただし， $\operatorname{prob}(\cdot)$ は括弧内の事象が生じる確率を表わ ᄂ, $\operatorname{prob}(\cdot, \cdot)$ 注同時確率, $\operatorname{prob}(\cdot \mid \cdot)$ は条件付確率を 表わす．また，本論文では各構造物拉よびシステムの状 態は安全または破壊の 2 つの状態のいずれかで表わされ るものと仮定する.

式 (1) において, $\operatorname{prob}\left(A_{x}\right)$ は $m$ 個の構造物のうち $x$ 個の構造物が安全である確率であり, 構造物に働く外 力と構造物の強度とによって決定され, システムの形状 にはよらない值である。一方, $\operatorname{prob}\left(S_{s} \mid A_{x}\right)$ は， $m$ 個 の構造物のうち $x$ 個の構造物が安全である場合にシステ ムが安全である確率であり, 外力または構造物の強度の 大きさのどちらにも関倸なく, システムの形状扝よび， システムが安全であるために各構造物が満たすべき条件 によって決定される值である.ここで，安全である構造
物の数は確率変数 $X$ であると考えられ，非負の整数 $x$ に対して確率変数 $X$ が $x$ の值をもつ確率 $\operatorname{prob}\left(A_{x}\right)$, prob $\left(S_{s} \mid A_{x}\right)$ をそれぞれ $x$ の関数 $A_{X}(x), S_{X}(x)$ と 考えると，

$$
\begin{aligned}
& A_{X}(x)=\operatorname{prob}\left(A_{x}\right) \\
& S_{X}(x)=\operatorname{prob}\left(S_{s} \mid A_{x}\right)
\end{aligned}
$$

となり, 式 (1) はこの 2 つの関数を用いて

$$
{ }_{s} P=\sum_{x=0}^{m} A_{X}(x) \cdot S_{X}(x)
$$

と表わされる. 今後, この 2 つの関数をそれぞれ「構造 物の強度の関数」および「システムの形状の関数」とよ ぶ.

\section{（2）複数種類の構造物からシステムが構成されてい る場合}

システムが複数種類の構造物から構成されている場 合, システムの信頼性は式 (1) と同様にして次式で表わ される。

$$
\begin{aligned}
{ }_{s} P= & \operatorname{prob}\left(S_{s}\right)=\sum_{x_{1}=0}^{m_{1}} \cdots \sum_{x_{n}=0}^{m_{n}} \operatorname{prob}\left({ }_{1} A_{x_{1}}, \cdots,{ }_{n} A_{x_{n}}, S_{s}\right) \\
= & \sum_{x_{1}=0}^{m_{1}} \cdots \sum_{x_{n}=0}^{m_{n}} \operatorname{prob}\left({ }_{1} A_{x_{1}}, \cdots,{ }_{n} A_{x_{n}}\right) \\
& \cdot \operatorname{prob}\left(S_{s} \mid A_{x_{1}}, \cdots,{ }_{n} A_{x_{n}}\right) \cdots \cdots \cdots \cdots \cdots \cdots \cdots(5)
\end{aligned}
$$

ただし，システムは $n$ 種類のそれぞれ $m_{1}, \cdots, m_{n}$ 個の 構造物から構成されるとし， $i A_{x_{i}}$ は第 $i$ 種 $(i=1, \cdots$, $n ）$ 構造物が $x_{i}$ 個安全である事象を表わしている.

(1) と同様, 安全である各種類の構造物の数は確率変数 $X_{1}, \cdots, X_{n}$ であると考えられ，非負の整数からなる $\left(x_{1}, \cdots, x_{n}\right)$ に対して, 確率 $\operatorname{prob}\left({ }_{1} A_{x_{1}}, \cdots,{ }_{n} A_{x_{n}}\right)$ およ び $\operatorname{prob}\left(S_{s} \mid A_{x_{1}}, \cdots,{ }_{n} A_{x_{n}}\right)$ を，それぞれ $\left(x_{1}, \cdots, x_{n}\right)$ の関数 $A_{X_{1} \cdots X_{n}}\left(x_{1}, \cdots, x_{n}\right)$ および $S_{X_{1} \cdots X_{n}}\left(x_{1}, \cdots, x_{n}\right)$ と考える.つまり，

$$
\begin{aligned}
A_{X_{1} \cdots X_{n}}\left(x_{1}, \cdots, x_{n}\right) & =\operatorname{prob}\left(A_{x_{1}}, \cdots,{ }_{n} A_{x_{n}}\right) \\
& \cdots \cdots \cdots \cdots \cdots \cdots \cdots \cdots \cdots \cdots \cdots \cdots \cdots \cdots \cdots \cdots \cdots \cdots \cdots \cdots \\
S_{X_{1} \cdots X_{n}}\left(x_{1}, \cdots, x_{n}\right) & =\operatorname{prob}\left(\left.S_{s}\right|_{1} A_{x_{1}}, \cdots,{ }_{n} A_{x_{n}}\right)
\end{aligned}
$$

式 (5)，(6)，(7)より，システムが安全である確率は，

$$
\begin{aligned}
{ }_{s} P= & \sum_{x_{1}=0}^{m_{1}} \cdots \sum_{x_{n}=0}^{m_{n}} A_{X_{1} \cdots X_{n}}\left(x_{1}, \cdots, x_{n}\right) \\
& \cdot S_{X_{1} \cdots X_{n}}\left(x_{1}, \cdots, x_{n}\right) \cdots \cdots \cdots \cdots
\end{aligned}
$$

と表わされる.ここでも, 前と同様, システムの信頼性 は構造物の強度の関数 $A_{X_{1} \cdots X_{n}}\left(x_{1}, \cdots, x_{n}\right)$ とシステム の形状の関数 $S_{X_{1} \cdots X_{n}}\left(x_{1}, \cdots, x_{n}\right)$ とに分離されている. 以下 3. では前者の構造物の強度の関数を, 4. では後者 のシステムの形状の関数を扱い，その結果を用いて $\mathbf{5}$. でシステムの信頼性を再び扱うことにする. 


\section{3. 構造物の強度の関数}

1 種類の構造物からシステムが構成されている場合, 構造物の強度の関数は式 (2) に扔ける $A_{X}(x)$ で表わさ れる. ところが，これは $m$ 個の構造物のうち $x$ 個が安 全である事象が生じる確率である。ここで, 構造物の安 全性を評価する場合に考慮すべき確率変数としては, 一 般に, 構造物の強度 $R$, 荷重外力 $S$ が考えられ, 破壊 が起きない事象は $R \geqq S$ で与えられることから，ある 対象とする地震動を受けた場合に, この事象が発生する 確率 $\operatorname{prob}(R \geqq S)$ を構造物の信頼性と定義する. ま ず，この值が一定值 $q$ であると仮定する. また，実際 のシステムでは, 各構造物の強度 $R$, 荷重外力 $S$ の間 に相関が存在すると考えられるが，ここでは，簡単にす るため, これらの值はすべて互いに独立であり，したが って, 各構造物の破壊が独立事象であると仮定してい る.この場合, 二項分布の公式より，

$$
A_{X}(x)=\left(\begin{array}{c}
m \\
x
\end{array}\right) q^{x}(1-q)^{m-x}
$$

と求められる. さらに, 二項分布は構造物の総数 $m$ が 大きな值では正規分布に近似され，

$$
A_{X}(x)=\frac{1}{\sqrt{2 \pi} \sigma_{x}} \exp \left(-\frac{(x-\bar{x})^{2}}{2 \sigma_{x}^{2}}\right) \cdot
$$

ただし， $\bar{x} ， \sigma_{x}{ }^{2}$ はそれぞれ安全である構造物の数の平 均值および分散であり，

$$
\begin{aligned}
\bar{x} & =\sum_{x=0}^{m} x A_{X}(x)=m q \ldots \ldots \ldots \ldots \ldots \ldots \\
\sigma_{x}{ }^{2} & =\sum_{x=0}^{m}(x-\bar{x})^{2} A_{X}(x)=m q(1-q)
\end{aligned}
$$

である。

複数種類の構造物から システムが構成されている場 合, 構造物の強度の関数は, 各種類の構造物の破壊が独 立事象であると仮定すると，

$$
A_{X_{1} \cdots X_{n}}\left(x_{1}, \cdots, x_{n}\right)=\prod_{i=1}^{n} A_{X_{i}}\left(x_{i}\right) \cdots
$$

と表わされる. ところが，各種類の構造物に対して式 （9）が成立し，これを式（13）に代入すると，

$$
A_{X_{1} \cdots X_{n}}\left(x_{1}, \cdots, x_{n}\right)=\prod_{i=1}^{n}\left(\begin{array}{c}
m_{i} \\
x_{i}
\end{array}\right) q_{i}{ }^{x_{i}}\left(1-q_{i}\right)^{m_{i}-x_{i}}
$$

となる.この関数はさらに, 多次元正規分布

$$
\begin{array}{r}
A_{X_{1} \cdots X_{n}}\left(x_{1}, \cdots, x_{n}\right)=\frac{1}{\sqrt{(2 \pi)^{n}\left|\sum_{x}\right|}} \\
\cdot \exp \left[-(\boldsymbol{x}-\overline{\boldsymbol{x}}) \sum_{\left.x^{-1}(\boldsymbol{x}-\overline{\boldsymbol{x}})^{T} / 2\right]}\right.
\end{array}
$$

ただし，

$$
\begin{aligned}
& \boldsymbol{x}=\left(x_{1}, \cdots, x_{n}\right) \\
& \overline{\boldsymbol{x}}=\left(\bar{x}_{1}, \cdots, \bar{x}_{n}\right) \\
& \bar{x}_{i}=m_{i} q_{i} \cdots \cdots \cdots
\end{aligned}
$$

$$
\begin{aligned}
\Sigma_{x} & =\left(\begin{array}{ccc}
\sigma_{x_{1}}{ }^{2} & & \\
& \ddots & \\
0 & \ddots & \\
0 & \sigma_{x_{n}}{ }^{2}
\end{array}\right) \\
\sigma_{x_{i}}{ }^{2} & =m_{i} q_{i}\left(1-q_{i}\right)
\end{aligned}
$$

\section{で近似できる.}

式（9）から（20）における各構造物の信頼性 $q_{i}$ は従 来の信頼性理論から次式により確定值として求められ る.

$$
q_{i}=\int_{0}^{\infty} F_{s}(u) f_{R_{i}}(u) d u
$$

ただし, $F_{s}(u)$ は荷重外力 $u$ の確率分布関数であり, $f_{R_{i}}(u)$ は第 $i$ 種構造物の強度 $u$ の確率密度関数であ る.

しかし， $F_{s}(u)$ または $f_{R_{i}}(u)$ が確率変数である場 合には, 各構造物の信頼性 $q_{i}$ は確率量として求められ る. この信頼性の確率密度関数を $f_{Q_{i}}\left(q_{i}\right)$ とおくと, 式 （9）の代わりに, 次式

$$
A_{X_{i}}\left(x_{i}\right)=\left(\begin{array}{c}
m_{i} \\
x_{i}
\end{array}\right) \int_{0}^{1} f_{Q_{i}}\left(q_{i}\right) q_{i}^{x_{i}}\left(1-q_{i}\right)^{m_{i}-x_{i}} d q_{i}
$$

が成立する.したがって, 安全である構造物の総数の平 均値は, 式 (11) と同様にして,

$$
\bar{x}_{i}=m_{i} \bar{q}_{i}
$$

であり, 分散は式 (12) と同様にして,

$$
\sigma_{x_{i}}{ }^{2}=m_{i} \bar{q}_{i}\left(1-\bar{q}_{i}\right)+m_{i}\left(m_{i}-1\right) \sigma_{q_{i}}{ }^{2}
$$

と求められる.ただし， $\bar{q}_{i}, \sigma_{q_{i}}{ }^{2}$ はそれぞれ信頼性 $q_{i}$ の 平均值および分散

$$
\begin{aligned}
\bar{q}_{i} & =\int_{0}^{1} q_{i} f \boldsymbol{Q}_{i}\left(q_{i}\right) d q_{i} \ldots \ldots \ldots . . . \\
\sigma_{q_{i}}{ }^{2} & =\int_{0}^{1}\left(q_{i}-\bar{q}_{i}\right)^{2} f \boldsymbol{Q}_{i}\left(q_{i}\right) d q_{i} .
\end{aligned}
$$

を示している. 結局, 構造物の信頼性が確率変数である 場合の構造物の強度の関数は, 式 (23), (24) の平均值 および分散を有する多次元正規分布（式 (15)) で近似で きる. 式 (18) と（23）および式（20）と（24）を比較 すると, 構造物の信頼性が確定值のまわりに分布するこ とにより構造物の強度の関数の平均値は変わらないが, 分散が $m_{i}\left(m_{i}-1\right) \sigma_{q_{i}}{ }^{2}$ だけ大きくなることが認められ る. なお, 信頼性が確率変数である一種類の構造物から 構成されているシステムに対する構造物の強度の関数は 式（21）から（26）において添字 $i$ を取り除けば同様 に成立することはいうまでもない。

\section{4. システムの形状の関数}

（1） システムの形状の関数の算定方法（1）—すべ ての順列組合せを考える方法一

システムの形状の関数 $S_{X}(x)$ または $S_{X_{1} \cdots X_{n}}\left(x_{1}, \cdots\right.$, 
$x_{n}$ ）の厳密解 は 以下の手順に従い算定することができ る.ただし, $S_{X}(x)$ は $S_{X_{1} \cdots X_{n}}\left(x_{1}, \cdots, x_{n}\right)$ で $n$ が1の 場合であるので, 後者の場合について理論を進める.

(1) 第 $i$ 種の $m_{i}$ 個の構造物に 1 から $m_{i}$ の番号を 割り当てる. この操作を $i=1, \cdots, n$ の全種類の構造物 について行う.

(2) 1 $m_{i}$ を並び変えて $m_{i}$ ! 個の順列を作り，これ らの順列の全種類についての組合せを求めると $\prod_{i=1}^{n} m_{i}$ ! 個の順列組合せが得られる.

(3)それぞれの順列組合せに対し，各順列を破壊しに くい構造物の順序に並んだ列つまり（構造物の強度 $R$ ) 一(荷重外力 $S$ ) の值が大きな順序に並んだ列であると 考え, 最初から $x_{i}$ 個の構造物は安全であり, それ以降 の構造物は破壊するものと考える. $0 \leqq x_{i} \leqq m_{i}(i=1$, $\cdots, n)$ の範囲のすべての整数の $n$ 種類の構造物につい ての全組合せを表わすべクトル $\left(x_{1}, \cdots, x_{n}\right)$ に対して, システムが安全であるか否かをシステムの破壊の基準に 従い判定する.

(4) 構造物の種類により破壊確率が異なっていても， また， 3. で扱ったように，同一種類の構造物の破壊確 率が分布していても，同一種類の構造物の間では信頼性 の大小を確定できない場合には, (2) の $\prod_{i=1}^{n} m_{i}$ ! 個の順 列組合せそれぞれの発生確率は等しく $1 / \prod_{i=1}^{n} m_{i}$ ! であ る. (3) の手順をすべての順列組合せに対して適用し, システムが安全となる順列組合せの数を $\left(x_{1}, \cdots, x_{n}\right)(0$ $\left.\leqq x_{i} \leqq m_{i}, i=1, \cdots, n\right)$ の関数として数え上げ，その 数を $s\left(x_{1}, \cdots, x_{n}\right)$ とおくとシステムの形状の関数の厳 密解は,

$$
S_{X_{1} \cdots X_{n}}\left(x_{1}, \cdots, x_{n}\right)=s\left(x_{1}, \cdots, x_{n}\right) / \prod_{i=1}^{n} m_{i} !
$$

で算定される. 構造物の種類および個数の増加に伴う, 順列組合せの数の増加が著しいため, 実際の複雑なシス テムに対し本方法を適用することは非常に困難である. 本方法は比較的単純なシステムに対してのみ適用可能で ある。

\section{（2） システムの形状の関数の算定方法 (2)—モン テカルロ法による方法—}

（1）で扱ったようにすべての順列組合せを考える方法 では, 構造物の個数の増大に伴い, 順列組合せの総数 $\left(\prod_{i=1}^{n} m_{i} !\right)$ は急速に増大するため, 実際の複雑なシステ ムに対して (1) の方法は実用的ではない.そこで，すべ ての順列を扱う代わりに順列をランダムに生成し, シス テムの形状の近似関数をモンテカルロ法により算定する 方法が考えられる. 順列をランダムに生成するには，ま
ず1〜 $m_{i}$ の自然数のそれぞれに対してランダムな数を発 生させ割り当て, これらのランダム数を大きさの順に並 び変え, 同時に対応する $1 \sim m_{i}$ の自然数も並び変え, 得られた自然数の列をランダムに取り出された順列と考 える.

上記以外の点では (1) の算定方法と同様であり, 各種 類の構造物に対し $m_{i}^{*}(i=1, \cdots, n)$ 個の順列をシミュ レートした場合に得られる $\prod_{i=1}^{n} m_{i}{ }^{*}$ 個の順列組合せのう ち, システムが安全である順列組合せの数を $\left(x_{1}, \cdots\right.$, $\left.x_{n}\right)$ の関数として数え上げ，その数を $s^{*}\left(x_{1}, \cdots, x_{n}\right)$ とすると, システムの形状の関数の近似解は,

$$
S_{X_{1} \cdots X_{n}}\left(x_{1}, \cdots, x_{n}\right) \fallingdotseq s^{*}\left(x_{1}, \cdots, x_{n}\right) / \prod_{i=1}^{n} m_{i}^{*}
$$

で算定される。

\section{（3） システムの形状の関数の算定方法 (3)—Tie- set または Cut-set を用いる方法——}

供給節点と需要節点とが連結の場合にシステムが安全 であるとシステムの安全性について特に基準を設けた場 合には, Tie-set または Cut-set を用いてシステムの形 状の関数を算定することが可能である. 各種類の構造物 がそれぞれ $x_{i}$ 個 $(i=1, \cdots, n)$ 安全である場合にシステ ムが安全である確率は, 各種類の構造物に対する順列の 最初の $x_{i}$ 個の構造物の $n$ 種類の構造物にわたっての組 合せによって生じる構造物の集合 $S_{x_{1} \cdots x_{n}}$ に，少なくて もひとつの Tie-set が含まれる順列組合せの数の順列組 合せの総数 $\left(\prod_{i=1}^{n} m_{i} !\right)$ に対する割合に等しい.つまり,

$$
\begin{aligned}
& S_{X_{1} \cdots X_{n}}\left(x_{1}, \cdots, x_{n}\right)=\operatorname{prob}\left(S_{s} \mid A_{x_{1}}, \cdots,{ }_{n} A_{x_{n}}\right) \\
& =\operatorname{prob}\left(\text { any Tie-set } \subset S_{x_{1} \cdots x_{n}}\right. \text { ) } \\
& =\frac{1}{\prod_{i=1}^{n} m_{i} !} s\left(\text { any Tie-set } \subset S_{x_{1} \cdots x_{n}}\right) \\
& =\frac{1}{\prod_{i=1}^{n} m_{i} !} \sum_{h=1}^{N T}(-1)^{h-1} \sum_{j=1}^{N C_{h}} s\left(\underset{k \in I_{j} h}{\bigcup} T . S_{k} \subset S_{x_{1} \cdots x_{n}}\right) \\
& =\frac{1}{\prod_{i=1}^{n} m_{i} !} \sum_{h=1}^{N T}(-1)^{h-1} \sum_{j=1}^{N C_{h}} \prod_{i=1}^{n}\left(\begin{array}{c}
x_{i} \\
{ }_{i} s_{j}{ }^{h}
\end{array}\right)\left({ }_{i} s_{j}{ }^{h}\right) ! \\
& \cdot\left(m_{i}-{ }_{i} s_{j}{ }^{h}\right) !
\end{aligned}
$$

ただし， $s(\cdot)$ は括弧内の条件を満足する順列組合せの 総数, $T . S_{k}$ は $k$ 番目の Tie-set を構成する構造物の 集合, $N T$ は Tie-set $の$ 総数, $N C_{h}=\left(\begin{array}{c}N T \\ h\end{array}\right), I_{j}{ }^{h}$ は $N T$ 個の Tie-set から $h$ 個の Tie-set を取り出す組合 せのうち $j$ 番目の組合せを構成する要素である Tie-set の番号の集合, および, ${ }_{i} s_{j}{ }^{h}=\left|\underset{k \in I_{j} h}{\bigcup} T \cdot S_{k}\right|_{i}$ は $I_{j}{ }^{h}$ の要 素である番号の Tie-set の和集合を構成する構造物のう ち, 第 $i$ 種類の構造物の総数を表わす. また, 式 (29) 
では, 大きさ $m_{i}$ の列の最初の $x_{i}$ 個のうちに所定の ${ }_{i} s_{j}{ }^{h}$ 個を含む順列の数方 $\left(\begin{array}{c}x_{i} \\ { }_{i} s_{j}{ }^{h}\end{array}\right)\left({ }_{i} s_{j}{ }^{h}\right) !\left(m_{i}-{ }_{i} s_{j}{ }^{h}\right) ! て ゙$ 求められることを用いている.

Cut-set を用いても Tie-set の場合と同様にして各種 類の構造物がそれぞれ $x_{i}$ 個 $(i=1, \cdots, n)$ 安全である 場合にシステムが破壊する確率 $\operatorname{prob}\left(S_{f} \mid A_{x_{1}}, \cdots,{ }_{n} A_{x_{n}}\right)$ が求められ，これを次式

$$
\begin{aligned}
& S_{X_{1} \cdots X_{n}}\left(x_{1}, \cdots, x_{n}\right)=\operatorname{prob}\left(S_{s} \mid 1 A_{x_{1}}, \cdots,{ }_{n} A_{x_{n}}\right) \\
& \quad=1-\operatorname{prob}\left(S_{f} \mid{ }_{1} A_{x_{1}}, \cdots,{ }_{n} A_{x_{n}}\right) \cdots \cdots \cdots \cdots \cdots(30)
\end{aligned}
$$

に代入することによりシステムの形状の関数を算定でき る.

\section{（4） システムの形状の確率密度関数 $\boldsymbol{f}(\boldsymbol{y})$, $\boldsymbol{f}\left(\boldsymbol{y}_{1}, \cdots, \boldsymbol{y}_{n}\right)$ の導入}

システムの形状の関数は，構成構造物が 1 種類の場合 には式 (4) における $S_{X}(x)$ で,また, 複数種類の場合 には式 (8) に㧍ける $S_{X_{1} \cdots X_{n}}\left(x_{1}, \cdots, x_{n}\right)$ で表わされる

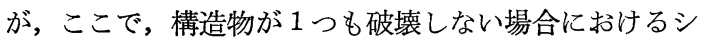
ステムの信頼性は 1 であることを用いると，

$$
\begin{aligned}
& S_{X}(m)=\operatorname{prob}\left(S_{s} \mid A_{m}\right)=1 \cdots \cdots \cdots \cdots \cdots \cdots(31) \\
& S_{X_{1} \cdots X_{n}}\left(m_{1}, \cdots, m_{n}\right)=\operatorname{prob}\left(S_{s} \mid A_{1} A_{m_{1}}, \cdots,{ }_{n} A_{m_{n}}\right) \\
& \quad=1 \cdots \cdots \cdots \cdots \cdots \cdots \cdots \cdots \cdots \cdots \cdots \cdots \cdots \cdots \cdots \cdots \cdots \cdots \cdots \cdots \cdots \cdots \cdots \cdots \cdots \cdots \cdots \cdots \cdots \cdots
\end{aligned}
$$

が成立する．また，システムの種類・形状，構造物の種 類等によって異なるものであるが，ここではどんな安全 なシステムに対しても，その場合に安全な構造物の集合 を含む集合の構造物が安全であるシステムは安全である ような場合を考える.この場合, システムの形状の関数 $S_{X}(x), S_{X_{1} \cdots X_{n}}\left(x_{1}, \cdots, x_{n}\right)$ は $x$ まをた $x_{1}, \cdots, x_{n}$ に関して単調増加関数である.

ここで 1 種類の構造物から構成されるシステムに対し 次の関数を定義する.

$$
f(y)=S_{X}(y)-S_{X}(y-1)
$$

ただし，

$$
S_{X}(y)=0(y \leqq-1)
$$

とする. 式 (31)，(33)，(34）を用いると, 次式が成立 する・

$$
\begin{aligned}
& \sum_{y=0}^{m} f(y)=1 \cdots \cdots \cdots \\
& S_{X}(x)=\sum_{y=0}^{x} f(y)
\end{aligned}
$$

$f(y)$ は安全な構造物の総数が $(y-1)$ 個からさらに 1 個増すことによるシステムの信頼性の増加分であり, 上 述したようにシステムの形状の関数が単調増加関数であ る場合には $f(y)$ は非負である.そこで $f(y)$ をシス テムの形状の確率密度関数とよぶことにする.

複数の種類の構造物から構成されるシステムに対して は, 式 (33) を㧒張し次の関数をシステムの形状の確率
密度関数として定義する.

$$
\begin{aligned}
f\left(y_{1}, \cdots, y_{n}\right)= & \sum_{r_{1}=0}^{1} \cdots \sum_{r_{n}=0}^{1}(-1) \sum_{j=1}^{n} r_{j} \\
& \cdot S_{X_{1} \cdots X_{n}}\left(y_{1}-r_{1}, \cdots, y_{n}-r_{n}\right)
\end{aligned}
$$

ただし， $y_{1}, \cdots, y_{n}$ のらちに負の数が 1 つでも含まれれ ば $S_{X_{1} \cdots X_{n}}\left(y_{1}, \cdots, y_{n}\right)$ は零であるとする. 式 (37) の 右辺の関数は,

$$
\frac{\partial^{n}}{\partial y_{1} \cdots \partial y_{n}} S_{X_{1} \cdots X_{n}}\left(y_{1}, \cdots, y_{n}\right)
$$

の後退差分であり，式（32），(37）を用いると，

$$
\begin{aligned}
& \sum_{y_{1}=0}^{m_{1}} \cdots \sum_{y_{n}=0}^{m_{n}} f\left(y_{1}, \cdots, y_{n}\right)=1 \cdots \cdots \cdots \cdots \cdots(39) \\
& S_{X_{1} \cdots X_{n}}\left(x_{1}, \cdots, x_{n}\right)=\sum_{y_{1}=0}^{x_{1}} \cdots \sum_{y_{n}=0}^{x_{n}} f\left(y_{1}, \cdots, y_{n}\right)
\end{aligned}
$$

の関係が成立している.

\section{（5） システムの形状の確率密度関数の性質}

（1）から（4）により求められるシステムの形状の確率 密度関数の性質を，1 種類の構造物から構成される以下 に示す簡単なシステムのモデルについて調べた.

(1) $m$ 個の構造物からシステムが構成され， $m$ 個全 部の構造物が安全な場合に限ってシステムが安全である 場合には，システムの形状の確率密度関数は,

$$
f(y)= \begin{cases}0 & (0 \leqq y \leqq m-1) \\ 1 & (y=m)\end{cases}
$$

である.

(2) $m$ 個の構造物からシステムが構成され，そのう ち特定の ${ }_{1} s_{1}{ }^{1}$ 個の構造物が安全である場合にシステム が安全である場合（需給節点が連結である場合にシステ ムが安全であると基準を設けた場合に，両節点の間には ${ }_{1} s_{1}{ }^{1}$ 個の構造物から構成されている Tie-set が1つしか ないトリー状のシステムの場合)，式 (29)，(33) を用い るとシステムの形状の確率密度関数は,

$$
f(y)=\frac{{ }_{1} s_{1}{ }^{1}\left(m-{ }_{1} s_{1}{ }^{1}\right) !(y-1) !}{m !\left(y-{ }_{1} s_{1}{ }^{1}\right) !}
$$

で表わされ， ${ }_{1} s_{1}{ }^{1} \leqq y \leqq m$ の範囲で正の值となり単調 増加関数である. Fig. 1 に $m=17,{ }_{1} s_{1}{ }^{1}=5,10,15$ の 場合について $f(y)$ を計算した結果を示してある。こ の図より， ${ }_{1} s_{1}{ }^{1}$ の值が大きいほど，分布は右に寄ってい ることがわかる。

(3) $m$ 個の構造物からシステムが構成され，そのう ち特定の ${ }_{1} s_{1}{ }^{1}$ 個または ${ }_{1} s_{2}{ }^{1}$ 個の構造物が安全である場 合にシステムが安全である場合(2)と同様な基準を設けた 場合に，需給節点間にはそれぞれが ${ }_{1} s_{1}{ }^{1}$ 個と ${ }_{1} s_{2}{ }^{1}$ 個の 構造物から構成されている2つの Tie-set が存在する場 合), 式 (29)，(33)よりシステムの形状の確率密度関数 


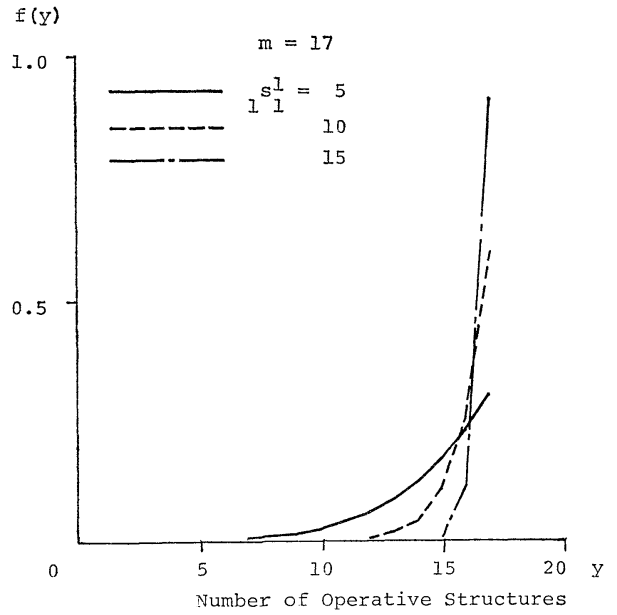

Fig. 1 Density Function Representing Redundancy due to System Configuration (in Case Supply and Demand Nodes are Connected to Each Other by Only One Tie-Set Composed of ${ }_{1} s_{1}{ }^{1}$ Structures).

は,

$$
\begin{aligned}
f(y)= & \frac{(y-1) !}{m !}\left[\frac{{ }_{1} s_{1}{ }^{1}\left(m-{ }_{1} s_{1}{ }^{1}\right) !}{\left(y-{ }_{1} s_{1}{ }^{1}\right) !}+\frac{{ }_{1} s_{2}{ }^{1}\left(m-{ }_{1} s_{2}{ }^{1}\right) !}{\left(y-{ }_{1} s_{2}{ }^{1}\right) !}\right. \\
& \left.-\frac{{ }_{1} s_{1}{ }^{2}\left(m-{ }_{1} s_{1}{ }^{2}\right) !}{\left(y-{ }_{1} s_{1}{ }^{2}\right) !}\right] \ldots \ldots \ldots \ldots \ldots \ldots \ldots \ldots \ldots(43)
\end{aligned}
$$

と表わされる.ただし，2つの Tie-set が同一構造物を 含まず独立である場合には，

$$
{ }_{1} s_{1}{ }^{2}={ }_{1} s_{1}{ }^{1}+{ }_{1} s_{2}{ }^{1}
$$

であり，同一構造物を 1 つ上含むため従属である場合 には,

$$
{ }_{1} s_{1}{ }^{2}<{ }_{1} s_{1}{ }^{1}+{ }_{1} s_{2}{ }^{1}
$$

である. Fig. 2 に $m=17$ で $\left({ }_{1} s_{1}{ }^{1},{ }_{1} s_{2}{ }^{1},{ }_{1} s_{1}{ }^{2}\right)$ の值がそ れぞれ $(5,5,10),(5,10,15),(5,5,8),(5,10,13)$ である場合の関数 $f(y)$ を示してある.この図より， Tie-set が 2 つ場合には 1 つの場合とは異なり，極大 值を有する関数になり得ること, 特に 2 つの Tie-set が 独立な場合には $y=m$ で零となること, また, Tie-set を構成する構造物の数が多いほど, 分布は右に寄ってい ることがわかる。

(4) 形状の確率密度関数 $f(y)$ が求められているシ ステムに, システムの安全に無関係な構造物を 1 つ追加 して得られる新しいシステムに対する関数 $f^{*}(y)$ を算 定する.

現在のシステムに対して得られる各順列の最初の（ $y$ -1）個の構造物だけが安全である場合にはシステムは 破壊し, 最初の $y$ 個の構造物が安全である場合にシステ ムが安全となるような $y$ の值をすへてての順列に対して求 め, $y$ の関数としてその順列の個数を数え上げたものを $\bar{s}(y)$ と沶く.この関数は（1）, (4) で定義した関数 $s(y)$ の後退差分関数である。

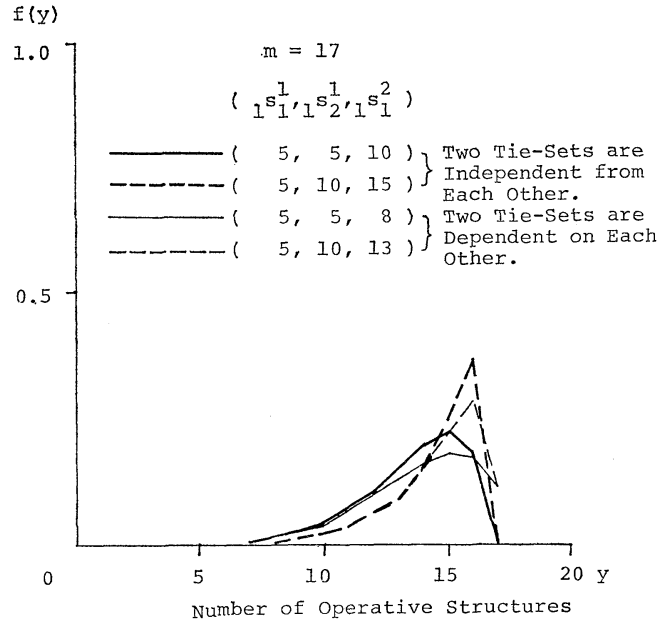

Fig. 2 Density Function Representing Redundancy due to System Configuration (in Case Supply and Demand Nodes are Connected to Each Other by Two Tie-Sets Composed of ${ }_{1} s_{1}{ }^{1}$ and ${ }_{1} s_{2}{ }^{1}$ Structures Respectively).

$$
\bar{s}(y)=s(y)-s(y-1)
$$

新しいシステムの構造物の総数を $(m+1)$ とおくと考慮 すべき順列の個数は $(m+1)$ ! である. この $(m+1)$ ! 個 の順列は新しく追加する構造物の順番 $t(=1, \cdots, m+1)$ それぞれに対し， $t$ を除く $m$ 個の位置 $1, \cdots, t-1$, $t+1, \cdots, m+1$ に現在のシステムに対する $m$ ! 個の順列 を並べたものであると分けて考えることができる. 追加 する構造物の番号が $t$ の場合の上述の後退差分関数を $\bar{s}_{t}^{*}(y)$ と㧍くと, 追加する構造物がシステムの安全に 寄与しないことから $m$ ! 個の順列のうち $(t-1)$ 以前の $y$ で安全となっている順列は, 新しいシステムの対応す る順列でもちょうど $y$ で安全となり, $t$ 以降の $(y-1)$ で安全となっている順列はちょうど $y$ で安全となるの で,

$$
\bar{s}_{t} *(y)= \begin{cases}\bar{s}(y) & y \leqq t-1 \\ 0 & y=t \\ \bar{s}(y-1) & y \geqq t+1\end{cases}
$$

ところが, 新しいシステムに対する後退差分関数は

$$
\bar{s}^{*}(y)=\sum_{t=1}^{m+1} \bar{s}_{t}^{*}(y)
$$

で表わされる.式 (48)，(47)より，したがって，

$$
\begin{aligned}
\bar{s}^{*}(y) & =\sum_{t=1}^{y-1} \bar{s}_{t}^{*}(y)+\bar{s}_{y}^{*}(y)+\sum_{t=y+1}^{m+1} \bar{s}_{t}^{*}(y) \\
& =(y-1) \bar{s}(y-1)+(m-y+1) \bar{s}(y)
\end{aligned}
$$

ところが，式 (27)，(33)，(46) より，

$$
\begin{aligned}
& \bar{s}(y)=m ! f(y) \ldots \ldots \ldots \ldots \\
& \bar{s}^{*}(y)=(m+1) ! f^{*}(y)
\end{aligned}
$$

が成立し, 結局, 新しいシステムの形状の確率密度関数 は次式により求められる. 


$$
f^{*}(y)=\frac{y-1}{m+1} f(y-1)+\frac{m-y+1}{m+1} f(y)
$$

(5) 形状の 確率密度関数 $f(y)$ が求められているシ ステムに, システムの安全をその 1 つの構造物のみでも 達成させるような構造物を1つ追加して得られる新しい システムに対する関数 $f^{*}(y)$ を算定する.

(4) と同様に考えると, $(t-1)$ 以前の $y$ で安全となっ ている順列は新しいシステムでもちょうど $y$ で安全とな $\eta, t$ 以降で安全となっている順列はちょうど $t$ で安全 となることより，次式が成立する.

$$
\bar{s}_{t} *(y)= \begin{cases}\bar{s}(y) & y \leqq t-1 \\ \sum_{y=y}^{m} \bar{s}(y) & y=t \\ 0 & y \geqq t+1\end{cases}
$$

したがって，式（48）より，

$$
\begin{aligned}
\bar{s}^{*}(y) & =\sum_{t=1}^{y-1} \bar{s}_{t}^{*}(y)+\bar{s}_{y}^{*}(y)+\sum_{t=y+1}^{m+1} \bar{s}_{t}^{*}(y) \\
& =\sum_{y=y}^{m} \bar{s}(y)+(m-y+1) \bar{s}(y) \cdots \cdots \cdots
\end{aligned}
$$

式 (50)，(51) を式 (54) に代入すると, 結局, 新しい システムの形状の確率密度関数は次式により求められ る.

$$
f^{*}(y)=\frac{1}{m+1}\left\{\sum_{y=y}^{m} f(y)\right\}+\frac{m+1-y}{m+1} f(y)
$$

\section{（6） システムの形状の確率密度関数の母数}

上述したように, システムの形状の確率密度関数は, 各構造物に作用する荷重外力の大きさにはよらず, シス テムの形状, およびシステムが安全であるために各構造 物が満たすべき条件によって決定される, システムの元 長度を表わすシステムに固有な関数である. 1 種類の構 造物から構成されているシステムに対して，この関数の 性質を表わす值として, 平均值 $\bar{y}$, および 分散 $\sigma^{2}{ }^{2}$ を 考える.

$$
\begin{aligned}
\bar{y} & =\sum_{y=0}^{m} y f(y) \cdots \ldots \ldots . . \\
\sigma_{y}{ }^{2} & =\sum_{y=0}^{m}(y-\bar{y})^{2} f(y)
\end{aligned}
$$

ここで, $\bar{y}$ が構造物の総数 $m$ に比較して小さいほど, 圥長なシステムを表わして抢り， $\sigma_{y}{ }^{2}$ は圥長度の分布の 大きさを示しているものと考学れる.なお， $\bar{y}$ は $\mathrm{M}$. Tainiter ${ }^{11)}$ により提案された連結グラフ $G$ の “mean connectivity" $c(G)$ と

$$
\bar{y}=m-c(G)
$$

の関係がある.

複数種類の構造物から構成されるシステムに対して も, 同様に, システムの形状の確率密度関数の平均ベク
トル

$$
\overline{\boldsymbol{y}}=\left(\bar{y}_{1}, \cdots, \bar{y}_{n}\right)
$$

ただし，

$$
\bar{y}_{i}=\sum_{y_{1}=0}^{m_{1}} \cdots \sum_{y_{n}=0}^{m_{n}} y_{i} f\left(y_{1}, \cdots, y_{n}\right)
$$

打よび分散行列

$$
\Sigma_{y}=\left(\sigma_{y_{i j}}{ }^{2}\right)
$$

ただし，

$$
\sigma_{y_{i j}}{ }^{2}=\sum_{y_{1}=0}^{m_{1}} \ldots \sum_{y_{n}=0}^{m_{n}}\left(y_{i}-\bar{y}_{i}\right)\left(y_{j}-\bar{y}_{j}\right) f\left(y_{1}, \cdots, y_{n}\right)
$$

により, システムの午長さの程度が表わされるものと考 える.

\section{5. システムの信頼性の算定}

1 種類の構造物からシステムが構成されている場合, システムの信頼性 ${ }_{s} P$ は, 式 (4), (36) より構造物の 強度の関数 $A_{X}(x)$ とシステムの 形状の確率密度関数 $f(y)$ とを用いて次のように表わされる.

$$
{ }_{s} P=\sum_{x=0}^{m} A_{X}(x) \sum_{y=0}^{x} f(y)
$$

ところが, 式 (33)，(34)より

$$
f(y)=0 \quad(y \leqq-1)
$$

であり，また定義より明らかに，

$$
\begin{aligned}
& A_{X}(x)=\operatorname{prob}\left(A_{x}\right)=0 \\
& \quad(x \leqq-1 \text { または } x \geqq m+1)
\end{aligned}
$$

であることから, この值は $x$ が $y$ 以上である確率を示 していることになり，

$$
{ }_{s} P=\operatorname{prob}(x-y \geqq 0)
$$

ここで, 式 (11)，(23)，(56) で表わされる $x$ および $y$ の平均值 $\bar{x}, \bar{y}$ を用いてシステムの中央安全率 $\alpha$ を

$$
\alpha=\frac{\bar{x}}{\bar{y}}
$$

で定義する. 式 (11) で $q=\bar{q}$ とおいた式または式 (23) を式（67）に代大するとともに次式で表わされ，

$$
\alpha=\frac{\bar{q}}{\bar{y} / m}
$$

各構造物の信頼性が一定值 $\bar{q}$ の場合にも, また平均值 $\bar{q}$ のまわりに分布する場合にも, システムの中央安全 率 $\alpha$ は同一であることがわかる. 式 (68) の分母は, 各 構造物の破壞が独立である場合に, システムが安全であ るために安全である必要がある構造物の数の下限の平均 值 $\bar{y}$ が，構造物の総数 $m$ に対する割合を示しており， この割合に対する各構造物の信頼性の平均值 $\bar{q}$ がシス テムの中央安全率 $\alpha$ となっている.

構造物の強度の関数 $A_{X}(x)$ が式 (10) で, また, シ ステムの形状の確率密度関数 $f(y)$ が次式 


$$
f(y)=\frac{1}{\sqrt{2 \pi} \sigma_{y}} \exp \left(-\frac{(y-\bar{y})^{2}}{2 \sigma_{y}{ }^{2}}\right)
$$

でともに正規分布と近似できる場合には, システムの信 頼性 ${ }_{s} P$ はより簡単に求めることができる.つまり,

$$
z=x-y
$$

とおくと, $z$ 注平均值 $\bar{z}$, 分散 $\sigma_{z}{ }^{2}$

$$
\begin{aligned}
& \bar{z}=\bar{x}-\bar{y} \cdots \cdots \\
& \sigma_{z}{ }^{2}=\sigma_{x}{ }^{2}+\sigma_{y}{ }^{2}
\end{aligned}
$$

の正規分布をする.ところが，システムが安全な確率 ${ }_{s} P$ は, 式 $(66),(70) よ り, z$ の確率密度関数 $f_{z}(z)$ を $z \geqq 0$ の領域で積分した值である.つまり，

$$
\begin{aligned}
& { }_{s} P \fallingdotseq \sum_{z=0}^{m} f_{z}(z) \\
& \fallingdotseq \frac{1}{\sqrt{2 \pi \sigma_{z}}} \int_{0}^{\infty} \exp \left(-\frac{(z-\bar{z})^{2}}{2 \sigma_{z^{2}}}\right) d z \\
& =1-\Phi\left(-\frac{\bar{z}}{\sigma_{z}}\right) \\
& =1-\Phi\left(-\frac{\bar{x}-\bar{y}}{\sqrt{\sigma_{x}^{2}+\sigma_{y}^{2}}}\right)
\end{aligned}
$$

ただし，

$$
\Phi(z)=\frac{1}{\sqrt{2 \pi}} \int_{-\infty}^{z} \exp \left(-\frac{z^{2}}{2}\right) d z
$$

である.ここで, 安全性指標 $\alpha^{*} を$

$$
\alpha^{*}=\frac{\bar{x}-\bar{y}}{\sqrt{\sigma_{x}^{2}+\sigma_{y}^{2}}}
$$

と定義すると，

$$
{ }_{s} P=1-\Phi\left(-\alpha^{*}\right)
$$

が成立しており，安全性指標 $\alpha^{*}$ が大きいほど，システ ムは安全であることがわかる，以上に示した関係は，構 造系の信頼性解析において， $x$ を構造物の強度，y を構 造物に生じる応力, ${ }_{s} P$ を構造物の信頼性, $\alpha$ を構造物 の中央安全率， $\alpha^{*}$ を構造物の安全性指標と考えた場合 に成立する式と類似している。

式（75）に式（23），(24）を代入することにより，各 構造物の信頼性 $q$ が分布している場合のシステムの安 全性指標が次式のように表わされる.

$$
\alpha^{*}=\frac{m \bar{q}-\bar{y}}{\sqrt{m \bar{q}(1-\bar{q})+m(m-1) \sigma_{q}{ }^{2}+\sigma_{y}{ }^{2}}}
$$

また, 各構造物の信頼性が一定值の場合には, 式 (77) で $\sigma_{q}{ }^{2}=0$ の場合となっている. この式より，各構造物 の破壊が独立である場合に，システムが安全であるため に安全である必要がある構造物の個数の下限の平均值 y に比較し, 荷重外力により破壊しない構造物の期待数 $m \bar{q}$ が大きいほど，システムの信頼性が大きいことがわ かる.この結果は式（68）のシステムの中央安全率が意 味する結果と同じである. また，次の場合，

$$
m \bar{q}=\bar{y}
$$

つまり, 式 (68) よりシステムの中央安全率 $\alpha=1$ の場 合に抢けるシステムの信頼性 ${ }_{s} P$ 注式 (77)，(76) より
0.5 であり，この場合を境に以下の $2 つ の$ 領域に分けて 次のように考察できる.

$$
m \bar{q}>\bar{y}
$$

の範囲，つまり

$$
{ }_{s} P>0.5
$$

の範囲では, 各構造物の信頼性の分散 $\sigma_{q}{ }^{2}$, または各構 造物の破壊が独立である場合に，システムが安全である ために安全である必要がある構造物の個数の下限の分散 $\sigma_{y}{ }^{2}$ が小さいほど，システムの信頼性は大きくなること がわかる. 一方，

$$
m \bar{q}<\bar{y}
$$

つまり,

$$
{ }_{s} P<0.5
$$

の範囲では， $\sigma_{q}{ }^{2}, \sigma_{y}{ }^{2}$ が大きいほど，システムの信頼性 は大きくなることがわかる。

複数種類の構造物から システムが構成されている場 合，システムの信頼性は式 (8)，（40）より次のように表 わされる。

$$
\begin{aligned}
{ }_{s} P= & \sum_{x_{1}=0}^{m_{1}} \cdots \sum_{x_{n}=0}^{m_{n}} A_{X_{1} \cdots X_{n}}\left(x_{1}, \cdots, x_{n}\right) \\
& \cdot \sum_{y_{1}=0}^{x_{1}} \cdots \sum_{y_{n}=0}^{x_{n}} f\left(y_{1}, \cdots, y_{n}\right) \cdots \cdots
\end{aligned}
$$

ところが，この值は式（66）の場合と同様に，

$$
{ }_{s} P=\operatorname{prob}\left(\bigcap_{i=1}^{n} x_{i}-y_{i} \geqq 0\right) \text {. }
$$

である.ここで, 構造物の強度の関数が式 (15) で, シ ステムの形状の確率密度関数 $f\left(y_{1}, \cdots, y_{n}\right)$ が次式で, ともに多次元正規分布と近似できると仮定する.

$$
\begin{aligned}
& f\left(y_{1}, \cdots, y_{n}\right)=\frac{1}{\sqrt{(2 \pi)^{n}\left|\sum y\right|}} \\
& \cdot \exp \left[-(\boldsymbol{y}-\overline{\boldsymbol{y}}) \sum y^{-1}(\boldsymbol{y}-\overline{\boldsymbol{y}})^{T} / 2\right]
\end{aligned}
$$

ただし，

$$
\boldsymbol{y}=\left(y_{1}, \cdots, y_{n}\right)
$$

であり， $\overline{\boldsymbol{y}} ， \Sigma_{y}$ はそれぞれ式 (59)，(61）で表わされ るものとする. 多次元正規分布の平均および分散の再生 性より,

$$
z=x-y
$$

の確率密度関数は多次元正規分布,

$$
\begin{aligned}
f_{z}\left(z_{1}, \cdots, z_{n}\right)= & \frac{1}{\sqrt{(2 \pi)^{n}\left|\sum_{z}\right|}} \exp [-(z-\bar{z}) \\
& \left.\cdot \sum_{z^{-1}}(\boldsymbol{z}-\overline{\boldsymbol{z}})^{T} / 2\right] \cdots \cdots \cdots(88)
\end{aligned}
$$

ただし，

$$
\begin{aligned}
& \bar{z}=\overline{\boldsymbol{x}}-\overline{\boldsymbol{y}} \ldots \ldots \\
& \Sigma_{z}=\Sigma_{x}+\Sigma_{y}
\end{aligned}
$$

で表わされ, したがって, システムの信頼性は,

$$
\begin{aligned}
{ }_{s} P & =\sum_{z_{1}=0}^{m_{1}} \cdots \sum_{z_{n}=0}^{m_{n}} f_{z}\left(z_{1}, \cdots, z_{n}\right) \\
& \fallingdotseq \frac{1}{\sqrt{(2 \pi)^{n}\left|\sum_{z}\right|}} \int_{0}^{\infty} \cdots \int_{0}^{\infty} \exp [-(z-\bar{z})
\end{aligned}
$$




$$
\left.\cdot \sum_{z^{-1}}(\boldsymbol{z}-\overline{\boldsymbol{z}})^{T} / 2\right] d z_{1} \cdots d z_{n} \cdots \cdots \cdots \cdots \cdot(91)
$$

で求められる.

\section{6. 数值計算例}

前章まで, 少数種類の構造物から構成されるシステム の解析方法を展開した．本章では，この方法を簡単なモ デルに例として適用し，具体的に数值計算を行い，得ら れた結果について考察を加えた。

ネットワークシステムのモデルとして，節点とリンク の 2 種類の構造物から構成されている Fig. 3 に示す 2 つのシステム A， B を考える. システム A はトリー状

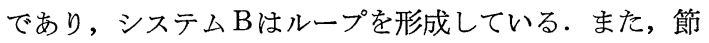
点の総数は両システムともに 12 個であり, リンクの総 数はそれぞれ 11 個および 17 個である.

システムは安全または破壊の必ずいずれか一方の状態 にあると仮定し, システムが安全であるための必要十分 条件として以下に示す 3 つ基準を考える.

(1)すべての節点が安全なリンクを介して連結してお り,かつ, 節点構造物がすべて安全である.

(II) 節点ペアの総数のらち一定割合以上の節点ペアが 安全なリンク，および節点を介して連結している. 本例 では 66 個の全節点ペアのうち, 約 $80 \%$ に相当する 53 個以上の節点ペアが連結している場合にシステムは安全 であるといら基準を設けた。

(11) システム内に含まれる $2 つ の$ 節点（供給節点と需 要節点）が安全なリンクおよび節点を介して連結してい る. 本例では節点 a と b (Fig. 3 参照)をそれぞれ供 給節点および需要節点とした.

まず, 節点構造物の信頼性は 1 である,つまり, 1 種 類の破壊するリンク構造物からシステムが構成されてい ると考えた.リンク構造物の信頼性を一定值 $(0.5,0.9$, 0.99) と仮定して, 構造物の強度の関数を式 (9) を用い て計算し，その結果をシステム $\mathrm{A}, \mathrm{B}$ それぞれに対し Fig. 4，5 亿示した. また，これらの分布の平均值およ び分散を式 (11)，(12）を用いて計算した。一方，シス テムの形状の確率密度関数 $f(y)$ をシステム $\mathrm{A}, \mathrm{B}$ そ れぞれに対し求めた結果を Fig. 6, 7 に, システムが 安全であるための基準 (I), (II), (III) それぞれに対し, 実 線, 一点鎖線, 破線を用いて示してある.ただし, シス テムAの基準 (1) と (11) に対しては，すべての順列組合 せを考慮して求めた厳密解を示し, 基準 囵に対して は, 厳密解と 100 回のシミュレーションによる近似解と の両方を示してある. 一方，システムBの基準 (1)，(1)， (11) に対しては, 100 回のシミュレーションによる近似 解を示してある. Fig. 6, 7 より, システムの形状の確 率密度関数は, トリー状のシステムAでは単調増加関数
System A
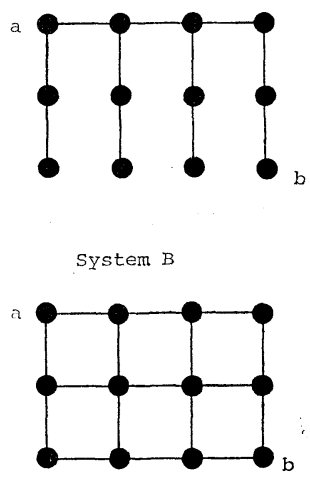

Fig. 3 Network Systems.

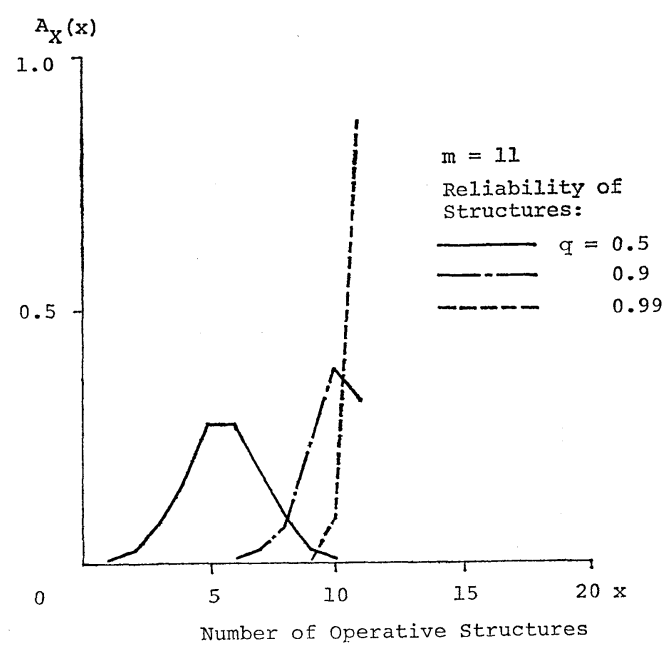

Fig. 4 Density Function Representing Structural Strength.

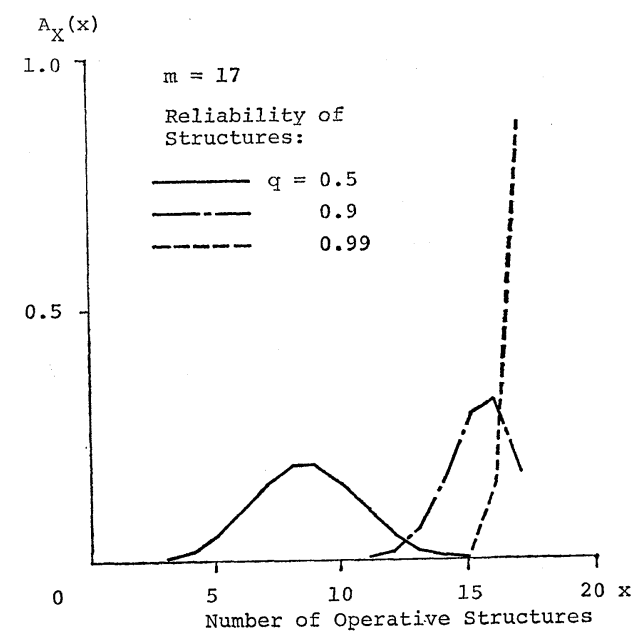

Fig. 5 Density Function Representing Structural Strength. 


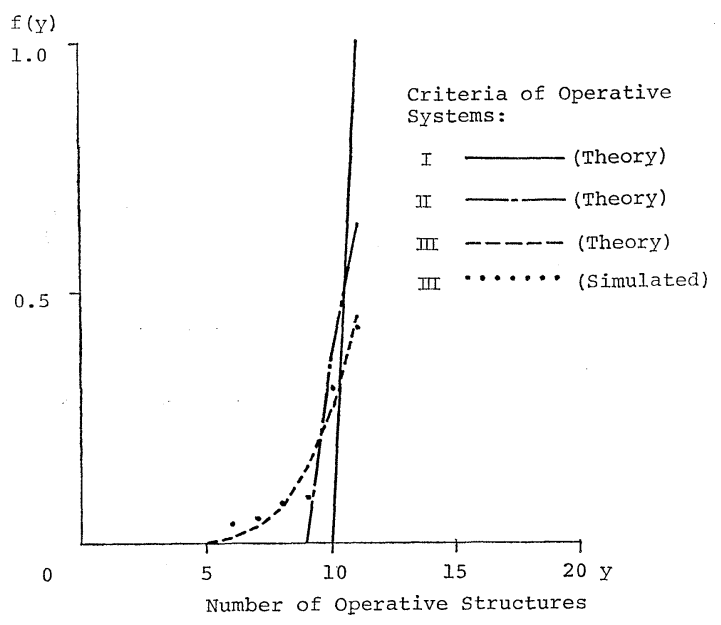

Fig. 6 Density Function Representing Redundancy due to Configuration of System A.

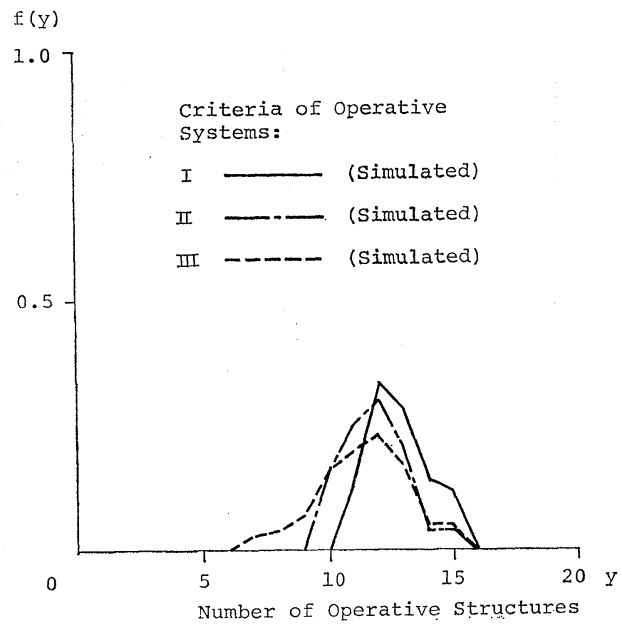

Fig. 7 Density Function Representing Redundancy due to Configuration of System B.

であるが，ループを形成するシステム Bでは極大值を有 する関数であることがわかり，この結果は，Fig. 1, 2 の Tie-set が 1 つまたは複数個存在する場合の結果と類 似している．これらの関数を比較することにより，荷重 外力の大きさに関係なくシステムの信頼性を直接比較す ることが可能である. Fig. 6, 7 いずれにおいても，基 準 (1), (1il), (目) の順序に分布が左に寄っていることから， 同一システム内においては，(1) よりも (17)，そしてさら に 而 の基準に対する信頼性が大きいことがわかる.さ らに, システム $\mathrm{A}$ と $\mathrm{B}$ との信頼性を直接比較するため, システムAにシステムの信頼性に無関係な構造物を 6 個 追加したシステム $A^{\prime}$ (Fig. 3 参照) を想定し, システ ムAの形状の確率密度関数に式 (52) を漸化式として順 次適用し，システム $\mathrm{A}^{\prime}$ に対する関数を求め，これを Fig. 8 に示してある. Fig. 7, 8 を比較すると, シス

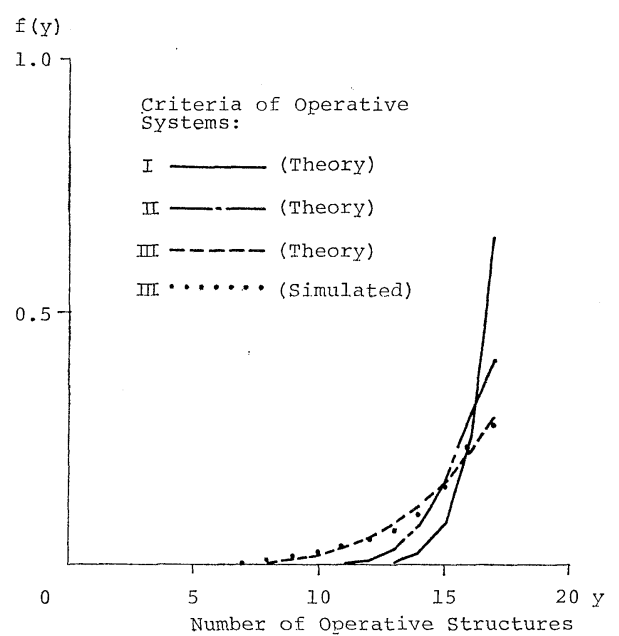

Fig. 8 Density Function Representing Redundancy due to Configuration of System $A^{\prime}$.

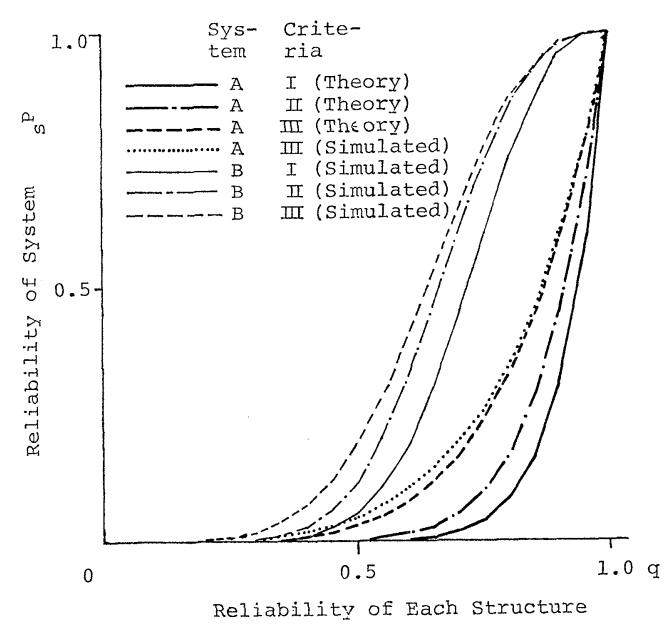

Fig. 9 Relationship between Reliability of System and That of Each Structure.

テムAの最も大きな信頼性を与える基準 囯よりも, シ ステム $\mathrm{B}$ の最も小さな信頼性を与える基準 (1) に対する 関数の方が, 左に寄って分布しており, 後者の基準に対 する信頼性が大きいことが認められる. 実際, システム の信頼性は構造物の強度の関数 (Fig. 4, 5) と システ ムの形状の確率密度関数（Fig. 6〜8）とを用いて, 式（63）により，見通しよく算定できる. 得られた結果 を Fig. 9 に, 横軸には構造物の信頼性 $q$ をとり, 縦 軸にはシステムの信頼性 ${ }_{s} P$ をとって, システムの種類 および安全性の基準をパラメーターとして示してある. 前述した結果と同じく, システムの信頼性はシステムB の (11), (11), (1) 続いてシステムAの (III, (1), (1) の順序に 高いことが認められる．さらに計算を簡略化するため， 式 (11)，(12) により求められる構造物の強度の関数の 平均值および分散と, Fig. 10 上方に示したシステムの 
形状の確率密度関数の平均值 $\bar{y}$ および分散 $\sigma_{y}{ }^{2}$ とを, 式（75）に代入してシステムの安全性指標を求め, さら に, 式 (76) によりシステムの信頼性を算定した. この 值を縦軸にとり，横軸に構造物の信頼性 $q$ をとって, システムの種類, および安全性の基準をパラメーターと して, Fig. 10 にこれらの関係を示してある. Fig. 10 の結果は Fig. 9 の結果をよく近似しているものと考 える.

次に, システム A, B の節点, リンクともに破壊し得 る,つまり， 2 種類の構造物からシステムが構成されて いると仮定して解析を行った. 構造物の強度の関数を式 （14）を用いて求め, その一例を Table 1 に示してあ る. ここでは, システムBを対象とし, 節点およびリン ク構造物の信頼性をそれぞれ一定值 $(0.9,0.8)$ と仮定 して計算を行った結果を示してある. 一方, システムの

\begin{tabular}{|c|c|c|c|c|c|}
\hline & $\begin{array}{l}\text { Sys- } \\
\text { tem }\end{array}$ & $\begin{array}{l}\text { Crite- } \\
\text { rion }\end{array}$ & $\begin{array}{l}\text { Techni- } \\
\text { que }\end{array}$ & $\begin{array}{l}\text { Mean } \\
\text { Value } \bar{Y}\end{array}$ & $\begin{array}{l}\text { Cova- } \\
\text { riance }\end{array} \sigma_{y}^{2}$ \\
\hline & $\mathrm{A}$ & I & Theory. & 11.00 & 0.00 \\
\hline-1 & A & II & Theory & 10.64 & 0.23 \\
\hline$--\cdots$ & A & IIII & Theory & 10.00 & 1.42 \\
\hline 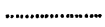 & A & III & Simulated & 9.87 & 1.91 \\
\hline & B & $I$ & Simulated & 12.79 & 1.43 \\
\hline-- & B & 표 & Simulated & 11.84 & 1.60 \\
\hline$-\cdots-\cdots$ & B & III & Simulated & 11.38 & 3.29 \\
\hline
\end{tabular}

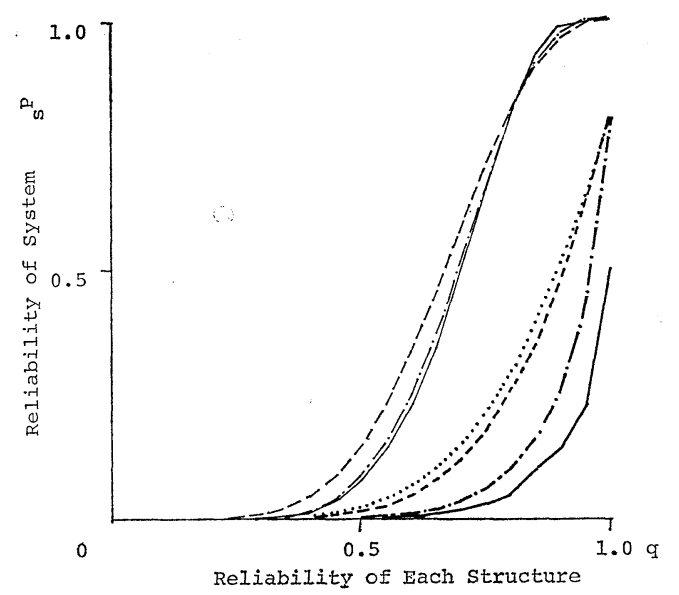

Fig. 10 Relationship between Reliability of Each Structure and That of System Calculated by Use of Safety Factor.

Table 1 Density Function Representing Structural Strength.

\begin{tabular}{|c|c|c|c|c|c|c|c|c|}
\hline & & \multicolumn{7}{|c|}{ Number of Operative Node Structures $x_{2}$} \\
\hline & & 6 & 7 & 8 & 9 & 10 & 11 & 12 \\
\hline \multirow{8}{*}{ 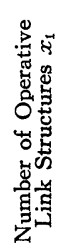 } & 4 & & & & & & 1 & \\
\hline & 5 & & & & 1 & 2 & 4 & 3 \\
\hline & 6 & & & 1 & 3 & 9 & 15 & 11 \\
\hline & 7 & & & 2 & 9 & 26 & 42 & 31 \\
\hline & 8 & & 1 & 5 & 19 & 51 & 83 & 63 \\
\hline & 9 & & 1 & 6 & 25 & 68 & 111 & 83 \\
\hline & 10 & & 1 & 5 & 20 & 54 & 89 & 67 \\
\hline & 11 & & & 2 & 7 & 20 & 32 & 24 \\
\hline
\end{tabular}

形状の確率密度関数を, システム $\mathrm{A}, \mathrm{B}$ それぞれと, 安 全性の基準 (I), (17)，(目) それぞれとの組合せに対して求 めた. 安全性の基準が (I) の場合には, すべての節点が 安全である場合にのみ, システムが安全であり得るた め, この関数は 1 種類の構造物からシステムが構成され ててる場合の結果 (Fig. 6, 7 の (1) ) と同一である. 安全性の基準 (III) に対するシステムAの形状の確率密度 関数を Table 2 に, システムBの関数を Table 3 に 示す. また, 安全性の基準 (iil) に対するシステム $A$ の関 数を Table 4 に, システムBの関数を Table 5 に示

Table 2 Density Function Representing Redundancy due to Configuration of System $A$ and Criterion II.

\begin{tabular}{|c|c|c|c|c|c|c|c|c|}
\hline & & \multicolumn{7}{|c|}{ Number of Operative Node Structures $y_{2}$} \\
\hline & & 6 & 7 & 8 & 9 & 10 & 11 & 12 \\
\hline \multirow{8}{*}{ 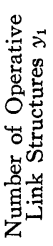 } & 4 & & & & & & & \\
\hline & 5 & & & & & & & \\
\hline & 6 & & & & & & & \\
\hline & 7 & & & & & & & \\
\hline & 8 & & & & & & & \\
\hline & 9 & & & & & & & \\
\hline & 10 & & & & & & 30 & 334 \\
\hline & 11 & & & & & & 303 & 333 \\
\hline
\end{tabular}

Table 3 Density Function Representing Redundancy due to Configuration of System $B$ and Criterion II.

\begin{tabular}{|c|c|c|c|c|c|c|c|c|}
\hline & \multicolumn{7}{|c|}{ Number of Operative Node Structures $y_{2}$} \\
\hline & & 6 & 7 & 8 & 9 & 10 & 11 & 12 \\
\hline \multirow{11}{*}{ 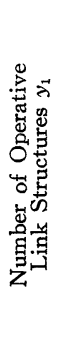 } & 7 & & & & & & & \\
\hline & 8 & & & & & & & \\
\hline & 9 & & & & & & & \\
\hline & 10 & & & & & & 2 & 12 \\
\hline & 11 & & & & & & 10 & 39 \\
\hline & 12 & & & & & & 18 & -1 \\
\hline & 13 & & & & & & 27 & -10 \\
\hline & 14 & & & & & & 23 & -21 \\
\hline & 15 & & & & & & 7 & -6 \\
\hline & 16 & & & & & & 9 & -9 \\
\hline & 17 & & & & & & 4 & -4 \\
\hline
\end{tabular}

Table 4 Density Function Representing Redundancy due to Configuration of System $A$ and Criterion III.

\begin{tabular}{|c|c|c|c|c|c|c|c|c|}
\hline & & \multicolumn{7}{|c|}{ Number of Operative Node Structures $y_{2}$} \\
\hline & & 6 & 7 & 8 & 9 & 10 & 11 & 12 \\
\hline \multirow{8}{*}{ 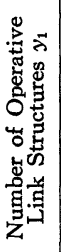 } & 4 & \multirow{8}{*}{1} & & & & & & \\
\hline & 5 & & & & & & 1 & 1 \\
\hline & 6 & & & & 1 & 2 & 2 & 6 \\
\hline & 7 & & & 1 & 2 & 4 & 10 & 15 \\
\hline & 8 & & 1 & 2 & 4 & 11 & 20 & 38 \\
\hline & 9 & & 1 & 3 & 10 & 20 & 41 & 77 \\
\hline & 10 & & 1 & 7 & 16 & 37 & 75 & 135 \\
\hline & 11 & & 4 & 9 & 28 & 62 & 124 & 228 \\
\hline
\end{tabular}


す.ただし，システムAに関しては厳密解を，システム Bに関しては 100 回のシミュレーションによる結果を示 してある. Table 2 より, システムA が基準 (III) に対 して安全であるためには，節点リンクとも 1 つまでの破 壊が許されること，しかし，双方とも破壊した場合には システムの安全確率は小さい $(3 \%)$ ことが認められる.

これに対し，Table 3 よりシステム B が同基準 (田 に 対して安全であるためには，節点は 1 つまで，リンクは 7 つまでの破壊が許されることがわかる．次に，Table 4 より, システムAが基準 目 に対して安全であるため には，節点リンクともそれぞれ最高 6 個の破壊が許され ること，しかし，ともにその上限近くまで破壊した場合 には，システムは破壊していることがわかる。また，

Table 5 より, システム B が基準 国 に対して安全で あるためには, 100 回のシミュレーションの結果では, 節点で最高 5 個の破壊まで, リンクで最高 10 個の破壊 までが許されることが示されている.しかし，この場合

Table 5 Density Function Representing Redundancy due to Configuration of System $B$ and Criterion III.

\begin{tabular}{|c|c|c|c|c|c|c|c|c|}
\hline & \multicolumn{7}{|c|}{ Number of Operative Node Structures $y_{2}$} \\
\hline & & 6 & 7 & 8 & 9 & 10 & 11 & 12 \\
\hline \multirow{11}{*}{ 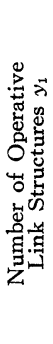 } & 7 & & \multirow{11}{*}{1} & & & \multicolumn{3}{|c|}{2} \\
\hline & 8 & & & & & & & 1 \\
\hline & 9 & & & & 1 & & 5 & 5 \\
\hline & 10 & & & & 2 & 4 & 4 & 9 \\
\hline & 11 & & & & 1 & 2 & 5 & 13 \\
\hline & 12 & & & & 2 & 2 & 7 & 1 \\
\hline & 13 & & & 1 & 4 & 6 & 4 & 5 \\
\hline & 14 & & & 1 & -1 & 9 & -2 & 2 \\
\hline & 15 & & & 3 & 4 & -4 & 3 & -3 \\
\hline & 16 & & & 3 & 1 & 8 & -5 & -6 \\
\hline & 17 & & & 2 & & 8 & -4 & -6 \\
\hline
\end{tabular}

も，ともに上限近くまで破壊した場合にはシステムは破 壞していることがわかる．システムの信頼性は，前と同 様に構造物の強度の関数とシステムの形状の確率密度関 数とを用いて，式（83）により算定できる．Table 6 にその結果の一例として, 安全性の基準 (III) に対するシ ステムBの信頼性を示してある.

\section{7. 結論}

（1） ライフラインシステムの多くは少数個の種類の 構造物が多数個集まり, システムを構成し機能している ことに注目して，システムの信頼性を各種類の構造物の 信頼性の影響を表わす関数と，システムの形状をネット ワーク状にすることの影響を表わす関数との 2 つの関数 で表わす方法を展開した。

（2）前者の関数は荷重外力の確率密度関数と構造物 の強度の確率密度関数とから求められる各種類の構造物 の信頼性を用いて算定される関数である.この関数は, 各種構造物の信頼性が一定值であるとみなせる場合には 二項分布関数で表わされ，また，信頼性が平均値のまわ りに分布する場合には，一定值である場合に比へ，平均 值は等しいが分散が大きな関数で表わされる.

（3）一方，後者のシステムの形状の影響を表わす関 数は, 荷重外力の大きさにはよらず，システムの形状と 安全性の基準とのみによる システムに固有な関数であ る.この関数の算定方法を，すべての順列組合せを考え る方法，モンテカルロ法による方法，Tie-set または Cut-set を用いる方法の 4 つの方法について示した. さ らに，簡単なシステムについてこの関数の性質を調べ, トリー状のシステムではこの確率密度関数は単調増加関 数となること，また，ループ状のシステムでは極大值を

Table 6 Relationship between Reliability of Each Structure and That of System B for Criterion III.

\begin{tabular}{|c|c|c|c|c|c|c|c|c|c|c|c|c|c|c|c|c|c|}
\hline & & \multicolumn{16}{|c|}{ Reliability of Node Structures $q_{2}$} \\
\hline & & 0.2 & 0.3 & & 0.4 & & 0.5 & & 0.6 & & 0.7 & & 0.8 & & 0.9 & & 1.0 \\
\hline \multirow{17}{*}{ 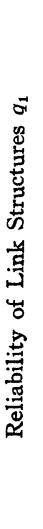 } & 0.2 & & & & & & & & & & & & & & 1 & 1 & 1 \\
\hline & & & & & & & & & & & & 1 & 1 & 2 & 3 & 4 & 5 \\
\hline & 0.3 & & & & & & & & & 1 & 1 & 2 & 3 & 5 & 7 & 10 & 13 \\
\hline & & & & & & & & & 1 & 2 & 3 & 5 & 8 & 12 & 17 & 24 & 31 \\
\hline & 0.4 & & & & & & 1 & 1 & 2 & 4 & 6 & 10 & 16 & 23 & 34 & 48 & 63 \\
\hline & & & & & & & 1 & 2 & 4 & 7 & 12 & 19 & 29 & 43 & 62 & 86 & 114 \\
\hline & 0.5 & & & & & 1 & 2 & 4 & 7 & 12 & 20 & 31 & 48 & 71 & 101 & 140 & 187 \\
\hline & & & & & 1 & 1 & 3 & 6 & 11 & 19 & 31 & 49 & 74 & 108 & 154 & 212 & 282 \\
\hline & 0.6 & & & & 1 & 2 & 5 & 9 & 17 & 28 & 46 & 72 & 107 & 155 & 218 & 298 & 394 \\
\hline & & & & 1 & 1 & 3 & 7 & 13 & 24 & 40 & 64 & 99 & 147 & 210 & 291 & 393 & 517 \\
\hline & 0.7 & & & 1 & 2 & 5 & 10 & 19 & 33 & 54 & 86 & 131 & 191 & 270 & 370 & 493 & 640 \\
\hline & & & & 1 & 3 & 7 & 14 & 25 & 44 & 71 & 111 & 166 & 239 & 333 & 449 & 590 & 756 \\
\hline & 0.8 & & 1 & 2 & 4 & 9 & 18 & 33 & 56 & 91 & 139 & 204 & 289 & 395 & 525 & 677 & 854 \\
\hline & & & 1 & 3 & 6 & 12 & 24 & 42 & 71 & 112 & 169 & 243 & 338 & 455 & 592 & 750 & 928 \\
\hline & 0.9 & & 1 & 3 & 8 & 16 & 30 & 52 & 86 & 134 & 199 & 283 & 386 & 509 & 649 & 805 & 974 \\
\hline & & & 1 & 4 & 9 & 19 & 36 & 62 & 101 & 156 & 229 & 321 & 432 & 559 & 698 & 844 & 995 \\
\hline & 1.0 & & 2 & 4 & 10 & 22 & 41 & 71 & 115 & 177 & 258 & 358 & 476 & 606 & 742 & 874 & 1000 \\
\hline
\end{tabular}


有する関数となる場合があることを示した.

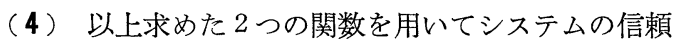
性を簡単に見通しょく算定する方法を展開した.さら に，この $2 つ の$ 関数が正規分布関数であると仮定できる 場合には, より簡単にシステムの信頼性が算定できるこ とを示し, 特に 1 種類の構造物からシステムが構成され ている場合に対し, 前記の 2 つの関数の平均值および分 散を用いたシステムの安全性指標を提案した.さらに, 簡単なシステムに対し実際に数值計算を行い, 以上の方 法が実用的であることを示した. システムの形状および 各構造物の信頼性が決定された 1 つの場合についてシス テムの耐震性を検討するためには, 従来のシミュレーシ ヨンを用いた方法が適していると考えられるのに対し, 本方法は, システムの形状および各種構造物の信頼性を さまざまに変化させて設定した多くの場合について, シ ステムの耐震性を簡単に見通しょく比較検討するために 適した方法を与えるものと考える。

\section{参 考 文 献}

1）たとえば, 岡本舜三 : 耐震工学, オーム社, 1971.

2) 久保慶三郎: 埋設管の地震時挙動, 生産研究, 25 巻 2 号, 1973.
3) Panoussis, G. : Seismic reliability of lifeline networks, Seismic Design Decision Analysis-Report No. 15, MIT, Dept. of Civil Eng. Res. Rep. R 74-57, 1974.

4) Taleb-Agha, G. : Seismic risk analysis of networks, Seismic Design Decision Analysis-Report No. 22, MIT, Dept. of Civil Eng. Res. Rep. R 75-49, 1975.

5) Shinozuka, M., S. Takada and H. Kawakami : Risk analysis of underground lifeline network systems, US-South East Asia Symposium on Engineering for Natural Hazards Protection, Manilla, Philippines, Sept., 1977.

6）柴田 碧・土屋雅彦：ライフラインの耐震性に関するシ ステム工学的研究, 東大機械工学研究報告, 第 13 巻, 1978.

7）田村重四郎・川上英二 : ライフラインのネットワークシ ステムの耐震性の一評価方法について, 生産研究, 30 巻 7 号, 1978 .

8）川上英二・田村重四郎：上水道管網システムの機能上の 耐震性の評価方法について, 土木学会第 34 回年次学術 講演会講演概要集, 1979.

9）田村重四郎・川上英二 : モンテカルロ法による地中埋設 管システムの耐震性の評洒方法, 土木学会論文報告集, 第 311 号, 1981.

10）伯野元彦・斉藤嘉則：ライフ・ラインの耐震性に影響す る因子, 第 15 回地震工学研究発表会講演概要, 1979 .

11) Tainiter, M. : A new deterministic network reliability measure, Networks, 6, 1976.

(1980.3.17 - 受付) 